\title{
PENINGKATAN PENGETAHUAN “MENCUCI TANGAN" PADA SISWA SEKOLAH DASAR MENGGUNAKAN MEDIA EDUKOMIK
}

\author{
Santria Darlis ${ }^{1^{*}}$; Rosini ${ }^{2 *}$ \\ ${ }^{1}$ Program Studi Ilmu Perpustakaan Universitas YARSI \\ ${ }^{2}$ Program Studi Perpustakaan dan Sains Informasi Universitas YARSI \\ *Korespondensi: *santriadarlis@gmail.com, rosini@yarsi.ac.id
}

\begin{abstract}
ABSTRAK
Penelitian ini bertujuan untuk mengetahui ada tidaknya pengaruh literasi informasi kesehatan melalui media edukomik terhadap peningkatan pengetahuan perilaku hidup bersih sehat, yaitu mencuci tangan pada anak-anak sekolah dasar. Jenis penelitian yang digunakan adalah kuantitatif dengan metode eksperimen menggunakan one group pretest-posttets. Teknik pengumpulan data dilakukan dengan penyebaran kuesioner. Jumlah sampel sebanyak 56 responden yang diambil secara purposive sampling. Data dianalisis dengan menggunakan SPSS dengan menghitung uji $\mathrm{T}$ (T-test). Berdasarkan hasil perhitungan dan uji $\mathrm{T}$ (t-Test) terdapat perbedaan nilai antara sebelum dan sesudah perlakuan pemberian informasi kesehatan. Sebelum perlakuan nilai rata-rata sebesar 7.2500 sedangkan setelah perlakuan nilai rata-rata sebesar 10.3214. Sedangkan hasil uji $\mathrm{T}$ dengan membandingkan taraf signifikan, dapat diketahui hasilnya nilai sig (2-tailed) nya sebesar 0.0000 yang artinya nilai signifikan nya adalah lebih besar dari 0.05 . Hal ini menunjukan bahwa hipotesis H0 ditolak dan H1 diterima. Artinya pemberian literasi informasi melalui media edukomik terdapat pengaruh yang signifikan terhadap peningkatan pengetahuan perilaku hidup bersih sehat mencuci tangan pada responden. Dapat disimpulkan bahwa pemberian literasi informasi kesehatan melalui media edukomik mampu meningkatkan pengetahuan anak terhadap perilaku hidup bersih sehat yaitu mencuci tangan. Untuk penelitian selanjutnya dapat dilakukan pada indikator perilaku hidup bersih sehat lainnya agar dapat dipastikan bahwa media edukomik dapat digunakan untuk memperomosikan kesehatan masyarakat.
\end{abstract}

Kata kunci: Literasi informasi kesehatan; Edukomik; Perilaku hidup bersih sehat; Mencuci tangan; PHBS, Sekolah Dasar

\section{PENDAHULUAN}

Komik sudah dikenal sebagai media hiburan anak-anak hingga dewasa. Komik pada umumnya dikenal sebagai cerita bergambar. Seperti menurut Soedjana \& Rivai (2011) komik adalah suatu bentuk kartun yang mengungkapkan karakter dan memerankan suatu cerita dalam urutan yang erat, dihubungkan dengan gambar dan dirancang untuk memberikan hiburan bagi pembacanya. Tanpa memasukan unsur hiburan, Soedarso (2015) mendefinisikan komik sebagai sebuah susunan gambar dan kata yang bertujuan untuk memberikan informasi yang ingin disampaikan kepada pembaca.

Komik mempunyai berbagai jenis seperti yang disampaikan oleh Dhien (2006), yaitu: komik superhero, komik laga, komik horror, komik roman, komik detektif, komik humor, 
komik spiritual, komik pendidikan, komik sport, komik wayang, dan komik seks. Komik yang menyajikan informasinya dalam bentuk gambar membuat kalangan tertentu menjadikan komik sebagai media pembelajaran atau edukasi. Maharsi dalam Soedarso (2015) menyatakan bahwa sebagai media edukasi, komik memiliki pengaruh yang besar dalam memberikan pemahaman yang cepat kepada para pembaca tentang suatu hal yang bermuatan edukasi. Peran komik dalam edukasi dapat ditemukan seperti di buku buku pelajaran TK yang menggunakan komik sebagai salah satu materi dalam pemberian informasi (Soedarso,2015) Komik dengan fungsi mengedukasi lazimnya disebut dengan edukomik atau educomic. Seperti yang disampaikan oleh Soedarso (2015) yang menyatakan penggunaan gambar pada buku pelajaran dinilai mampu untuk menyalurkan informasi yang mudah untuk dipahami walaupun yang ditampilkan dengan gambar yang sederhana. Gambar dan cerita menjadikan sebuah media pesan yang beragam. Sebuah komik yang baik harus memiliki fungsi yang baik pula, selain memiliki fungsi menghibur, sebuah komik pun juga harus memiliki fungsi yang meng edukasi para pembacanya, selalu memiliki pesan moral yang ingin disampaikan. Hal ini dikuatkan oleh pendapat Migotuwio (2013) yang menyatakan komik tidak hanya berhenti sebagai media hiburan saja. Namun dapat dialihkan dan dimanfaatkan secara maksimal sebagai media promosi, edukasi, dan informasi. Sehingga komik sangat tepat untuk menghadirkan tujuantujuan, pesan-pesan dengan tampilan yang menarik sebagai media yang menghibur sekaligus sebagai media pembelajaran yang sangat menyegarkan.

Literasi informasi kesehatan seringkali dikenal dengan "Health literacy". World Health Organization (WHO) mengemukakan literasi kesehatan sebagai kemampuan kognitif dan sosial yang menentukan motivasi dan kemampuan individu untuk mendapatkan akses, memahami dan menggunakan informasi dengan cara mempromosikan dan menjaga kesehatan yang baik. Sedangkan menurut Koh, Brach, Harris, \& Parchman (2013) mengemukakan "health literacy that is, their ability to obtain, process, communicate, and understand basic health information and services". Atau literasi kesehatan merupakan kemampuan mereka untuk memperoleh, memproses, dan mengomunikasikan, serta memahami dasar informasi dan layanan kesehatan.

Kesehatan pada anak usia dini perlu diperhatikan, terutama untuk anak sekolah dasar. Di dalam periode ini didapatkan banyak permasalahan kesehatan yang menentukan kualitas anak di kemudian hari. Permasalahan kesehatan tersebut pada umumnya akan menghambat pencapaian prestasi pada peserta didik di sekolah. Oleh karena itu diharapkan peran guru dan 
orang tua untuk ikut andil dalam memberikan literasi informasi kesehatan kepada anak. Perilaku hidup bersih dan sehat harus diterapkan sejak dini oleh para orang tua dan guru, mengingat bahwa pertumbuhan dan perkembangan pada anak usia sekolah dasar yang menjadi landasan utama tergantung dari pola hidup sehat. Undang-Undang Presiden Republik Indonesia Nomor 60 Tahun 2013 menyatakan bahwa peningkatan kualitas sumber daya manusia dalam pencapaian tumbuh kembang optimal sangat ditentukan oleh kualitas perkembangan anak selama periode usia dini yaitu sejak janin sampai anak berusia 6 (enam) tahun yang terlihat dari meningkatnya derajat kesehatan dan status gizi, kecerdasan dan keceriaan, pematangan emosional dan kesejahteraan anak. Sementara itu National Association for The Education of Young Children (NAEYC) menyampaikan bahwa anak usia dini itu anak yang berusia antara 0 sampai 8 tahun (Bredekamp, 1992) yang mendapatkan layanan pendidikan di taman penitipan anak, penitipan anak dalam keluarga (family child care home), pendidikan prasekolah baik negeri maupun swasta, taman kanak-kanak (TK) dan sekolah dasar (SD).

Perilaku Hidup Bersih dan Sehat (PHBS) merupakan perwujudan pada paradigma sehat dalam budaya perorangan, keluarga dan masyarakat yang berorientasi sehat, bertujuan meningkatkan dan memelihara kesehatannya baik fisik, mental, spiritual, maupun sosial (Kementerian Kesehatan, 2010). Perilaku Hidup Bersih dan Sehat (PHBS) adalah sekumpulan perilaku yang dipraktikkan atas dasar kesadaran sebagai hasil pembelajaran, yang menjadikan seseorang keluarga, kelompok atau masyarakat mampu menolong dirinya sendiri (mandiri) di bidang kesehatan dan berperan dalam mewujudkan kesehatan masyarakat (Kementerian Kesehatan, 2011). Menurut Proverawati \& Rahmawati (2012), terdapat delapan indikator yang dipakai sebagai ukuran untuk memulai PHBS di sekolah, antara lain adalah : a). Mencuci tangan dengan air yang mengalir dan memakai sabun, b) Mengkonsumsi jajanan sehat di kantin Sekolah, c) Menggunakan jamban yang bersih dan sehat, d) Olahraga yang teratur dan terukur, e) Memberantas jentik nyamuk, f) Tidak merokok di Sekolah, g) Menimbang berat badan dan mengukur tinggi badan setiap bulan, h) Membuang sampah pada tempatnya.

Dalam rangka meningkatkan taraf kesehatan anak usia sekolah, maka pemerintah mempromosikan hidup bersih dan sehat dengan membuat program Perilaku Hidup Bersih dan Sehat (PHBS) di sekolah. Salah satu yang ada dalam PHBS sekolah adalah mempromosikan kesehatan melalui tindakan "mencuci tangan". Program PHBS dapat diperkenalkan salah satunya dengan pemberian literasi informasi mengenai "mencuci tangan" dengan menggunakan 
edukomik sebagai media. Untuk melihat bagaimana efektivitas penggunaan edukomik dalam memberikan literasi informasi kesehatan PHBS mencuci tangan tersebut dapat dilihat dengan ada tidaknya pengaruh pemberian literasi informasi kesehatan melalui edukomik terhadap peningkatan pengetahuan siswa sekolah tentang PHBS mencuci tangan.

Apakah ada pengaruh pemberian literasi informasi kesehatan melalui educomic "mencuci tangan" terhadap peningkatan pengetahuan mengenai perilaku hidup bersih sehat "mencuci tangan" pada siswa sekolah dasar. Dengan rumusan masalah seperti tersebut di atas, maka tujuan dari penelitian ini adalah untuk mengetahui ada tidaknya pengaruh pengaruh pemberian literasi informasi kesehatan melalui educomic "mencuci tangan" terhadap peningkatan pengetahuan mengenai perilaku hidup bersih sehat "mencuci tangan" pada siswa sekolah dasar.

Sedangkan manfaat dari penelitian ini antara lain adalah:

1. Memberikan gambaran mengenai pengaruh literasi informasi kesehatan terhadap peningkatan perilaku hidup sehat dengan menggunakan media educomic pada siswa sekolah dasar

2. Sebagai alternatif media pembelajaran dengan menggunakan media educomic serta dapat membantu siswa/siswi dalam meningkatkan pengetahuan perilaku hidup bersih sehat.

3. Memberikan masukan bagi pemerintah cara meningkatkan perilaku hidup bersih sehat anak sekolah dasar salah satunya adalah dengan menyampaikan literasi informasi kesehatan melalui educomic.

\section{METODE}

Metodologi penelitian yang digunakan dalam penelitian ini adalah jenis kuantitatif dengan metode eksperimen. Menurut Sugiyono (2014), eksperimen yang dilakukan peneliti yaitu dengan one group pretest-posttest design (sebelum dan setelah diberikan tes pada kelompok sampel tertentu). Metode yang dilakukan berupa pemberian literasi informasi kesehatan tentang PHBS "mencuci tangan" yang disampaikan dengan membacakan komik yang memuat cerita tentang pentingnya mencuci tangan.

\section{$\mathrm{O}_{1} \mathrm{XO}_{2}$}

Gambar 1. Desain One group pretest dan posttest (Sugiyono, 2014) 
Bibliotech : Jurnal Ilmu Perpustakaan dan Informasi, 3 (1) 2018

Keterangan :

O1 : tes awal (pretest) sebelum perlakuan diberikan

$\mathrm{O} 2$ : tes akhir (posttest) setelah perlakuan diberikan

$\mathrm{X} \quad$ : pengaruh pemberian literasi informasi kesehatan melalui edukomik terhadap peningkatan pengetahuan mengenai PHBS mencuci tangan.

Data penelitian dari responden dikumpulkan dengan menggunakan instrumen kuesioner kemudian dianalisis dengan bantuan SPSS 20.00. Sedangkan teknik pengambilan sampel menggunakan "purposive sampling" terhadap 60 responden yang berusia maksimal 8 tahun di sebuah sekolah dasar di Jakarta Pusat. Pada saat filtering data responden, terdapat 4 anak yang berusia di atas 8 tahun, sehingga dikeluarkan dari data set. Sehingga yang diolah dalam kuesioner berjumlah 56 siswa.

Setelah melalui uji validitas dan reliabilitas kuesioner, maka selanjutnya variabel penelitian diuji dengan Uji T atau T-Test untuk membuktikan hipotesis. Dalam penelitian ini terdapat 2 variabel, variabel bebas dan variabel terikat sebagai berikut :

a. Literasi informasi kesehatan berupa pemberian pengetahuan mencuci tangan sebagai variabel bebas $(\mathrm{X})$

b. Peningkatan pengetahuan perilaku hidup sehat tentang mencuci tangan sebagai variabel terikat $(\mathrm{Y})$

Dengan adanya 2 variabel tersebut, maka hipotesis yang diajukan adalah: adanya pengaruh pemberian literasi kesehatan PHBS mencuci tangan terhadap peningkatan pengetahuan PHBS mencuci tangan dengan menggunakan edukomik. Dengan bantuan SPSS 20.00, t-Test dilakukan untuk melihat pengaruh variable $\mathrm{x}$ terhadap variable $\mathrm{Y}$ dengan ketentuan sebagai berikut :

$\mathrm{H} 0$ = tidak terdapat pengaruh yang signifikan diantara sesudah dan sebelum perlakuan penggunaan media edukomik terhadap peningkatan pengetahuan PHBS mencuci tangan.

$\mathrm{H} 1$ = terdapat pengaruh yang signifikan diantara sesudah dan sebelum perlakuan penggunaan media edukomik terhadap peningkatan pengetahuan PHBS mencuci tangan. 
Bibliotech : Jurnal Ilmu Perpustakaan dan Informasi, 3 (1) 2018

\section{HASIL DAN PEMBAHASAN}

\subsection{Hasil}

\subsubsection{Hasil Uji Hipotesis}

Uji t non-parametrik (t-Test) dilakukan untuk mengetahui apakah ada pengaruh peningkatan pengetahuan mencuci tangan sebelum dan sesudah diberi perlakuan dengan menggunakan media edukomik. Perhitungan t Test digunakan untuk membandingkan rata-rata dari dua group yang berpasangan, apakah kedua group tersebut mempunyai rata-rata yang sama atau signifikan. Jika nilai signifikansi $<0,05$ maka dapat dikatakan terdapat perbedaan pengetahuan mencuci tangan sebelum dan sesudah perlakuan. Apabila nilai probabilitas $>0,05$ maka tidak terdapat perbedaan tentang peningkatan mencuci tangan sebelum dan sesudah perlakuan.

Dari hasil perhitungan statistik deskriptif, maka diketahui nilai rata-rata pada sebelum perlakuan 7.2500 dan nilai rata rata setelah perlakuan 10.3214. disini terlihat bahwa nilai setelah perlakuan lebih tinggi dari pada sebelum perlakuan (Tabel 1).

Table 1. Deskripsi statistik

\begin{tabular}{|c|c|c|}
\hline & & Nilai rata-rata \\
\hline sebelum & 56 & 7.2500 \\
\hline sesudah & 56 & 10.3214 \\
\hline
\end{tabular}

Kemudian, dilakukan uji t untuk pengujian hipotesis dengan cara membandingkan taraf signifikan dengan kriteria keputusan : Jika nilai signifikan >0,05 maka H0 diterima, dan jika nilai signifikan $<0,05$ maka $\mathrm{H} 0$ ditolak.

Table 2. Tes statistik

\begin{tabular}{|l|r|}
\hline & prottest - pretest \\
\hline$Z$ & $-6.004^{\mathrm{b}}$ \\
\hline $\begin{array}{l}\text { Asymp. Sig. (2- } \\
\text { tailed) }\end{array}$ & .000 \\
\hline
\end{tabular}

Berdasarkan hasil output tabel t Test diketahui bahwa nilai sig (2-tailed) sebesar $0,000<$ 0,05 sehingga dapat disimpulkan bahwa terdapat perbedaan antara sebelum dan sesudah berlakuan pada penggunaan media edukomik maka H0 ditolak dan H1 diterima. Artinya bahwa 
pemberian literasi informasi melalui media edukomik terdapat pengaruh yang signifikan terhadap peningkatan pengetahuan perilaku.

Berdasarkan hasil penelitian data mencuci tangan memperoleh suatu kesimpulan bahwa ada pengaruh literasi informasi kesehatan melalui edukomik terhadap peningkatan pengetahuan perilaku hidup sehat mencuci tangan sebelum dan sesudah diberi perlakuan. Hal ini ditunjukan dari hasil uji t Test bahwa nilai sig. (2-tailed) sebesar $0,000<0,05$ artinya $\mathrm{t}$ hitung $<$ dari $\mathrm{t}$ tabel. Diketahui nilai sebelum diberi perlakuan yaitu sebesar 7.2500 dan setelah diberi perlakuan pengetahuan siswa terhadap perilaku hidup sehat menjadi meningkat yaitu sebesar 10.3214. Maka dari itu dapat dikatakan bahwa media edukomik dapat meningkatkan pengetahuan siswa terhadap perilaku hidup sehat mencuci tangan.

\subsubsection{Hasil Pengamatan Lapangan}

Berdasarkan hasil analisis dari kuesioner, maka data yang diperoleh dapat dilihat pada Tabel 1 di bawah ini:

Tabel 3. Peningkatan Pengetahuan Sebelum dan Setelah Literasi Informasi Kesehatan

\begin{tabular}{|c|l|c|c|c|c|}
\hline No. & \multicolumn{2}{|l|}{ Item Pertanyaan } & \multicolumn{2}{|c|}{ Sebelum } & \multicolumn{2}{c|}{ Setelah } \\
\cline { 3 - 6 } & Frekuensi & Persentase & Frekuensi & Persentase \\
\hline 1 & Rajin mencuci tangan & 27 & $51.8 \%$ & 49 & $87.5 \%$ \\
\hline 2 & $\begin{array}{l}\text { Mencuci tangan dengan } \\
\text { sabun }\end{array}$ & 37 & $66.1 \%$ & 54 & $96.4 \%$ \\
\hline 3 & $\begin{array}{l}\text { Mencuci tangan dengan } \\
\text { menggosok tangan, sela-sela } \\
\text { jari dan kuku }\end{array}$ & 35 & $62.5 \%$ & 53 & $94.6 \%$ \\
\hline 5 & $\begin{array}{l}\text { Menggunting kuku 1 } \\
\text { minggu sekali }\end{array}$ & 31 & $55.4 \%$ & 53 & $94.6 \%$ \\
\hline 6 & $\begin{array}{l}\text { Mencuci tangan sebelum } \\
\text { dan setelah makan }\end{array}$ & 46 & $82.1 \%$ & 53 & $94.6 \%$ \\
\hline 7 & $\begin{array}{l}\text { Mencuci tangan sebelum } \\
\text { makan }\end{array}$ & 36 & $64.3 \%$ & 52 & $92.9 \%$ \\
\hline 8 & $\begin{array}{l}\text { Mencuci tangan setelah } \\
\text { bermain }\end{array}$ & 35 & $62.5 \%$ & 53 & $94.6 \%$ \\
\hline 9 & $\begin{array}{l}\text { Mencuci tangan setelah } \\
\text { buang air besar }\end{array}$ & 47 & $83.9 \%$ & 50 & $89.3 \%$ \\
\hline $\begin{array}{l}\text { Mencuci tangan setelah } \\
\text { memegang hewan }\end{array}$ & 38 & $67.9 \%$ & 54 & $96.4 \%$ \\
\hline
\end{tabular}

Dengan memperhatikan Tabel 3 di atas, maka dapat disimpulkan bahwa secara keseluruhan semua pengetahuan tentang mencuci tangan yang disampaikan melalui edukomik, taerdapat peningkatan sebesar 27.5\%. Hampir semua responden mengalami peningkatan lebih 
dari $90 \%$ atau mendekati 100\%, kecuali untuk 2 pengetahuan, yaitu : "rajin mencuci tangan" sebesar 87.5\% dan "mencuci tangan setelah buang air besar" sebesar 89.3\%. Apabila diurutkan, terlihat peningkatan pengetahuan yang paling besar adalah "mencuci tangan dengan sabun" dan "mencuci tangan setelah memegang hewan" dengan persentase sebesar 96.4\%. Rata-rata peningkatan setiap pertanyaan dapat dilihat pada Gambar 2 di bawah ini.

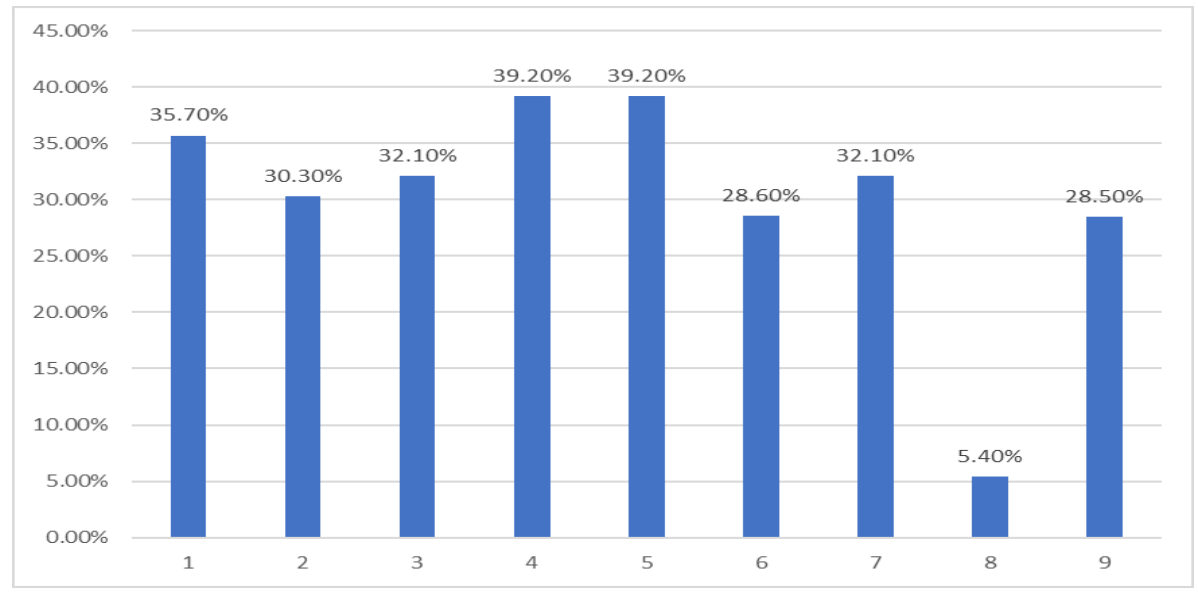

Gambar 2. Rata-rata Peningkatan Pengetahuan PHBS "Mencuci Tangan"

\subsection{Pembahasan}

Berdasarkan uji hipotesis dan hasil analisis dari kuesioner maka dapat diketahui bahwa pengetahuan siswa terhadap perilaku hidup sehat dengan menggunakan media edukomik sebelum dan sesudah diberi perlakuan manjadi meningkat, hasil ini disesuaikan dengan teori, yang disampaikan Maharsi (2011) dan Soedarso (2015) bahwa dalam perannya sebagai media edukasi memiliki pengaruh yang besar dalam memberi pemahaman yang cepat kepada para pembaca tentang suatu hal yang bermuatan edukasi (Maharsi dalam Soedarso, 2015) dan komik bukan sekedar membawa pesan edukasi dan bersifat hiburan (edutainment), melalui rangkain gambar, komik mampu mengemas sesuatu yang sulit jadi mudah dicerna. Begitu pun dengan yang disampaikan oleh Migotuwio (2013) yang menyatakan komik tidak hanya berhenti sebagai media hiburan saja. Namun dapat dialihkan dan dimanfaatkan secara maksimal sebagai media promosi, edukasi, dan informasi. Sehingga komik sangat tepat untuk menghadirkan tujuan-tujuan, pesan-pesan dengan tampilan yang menarik sebagai media yang menghibur sekaligus sebagai media pembelajaran yang sangat menyegarkan.

Hasil penelitian ini juga sejalan dengan hasil penelitian dari yang lakukan oleh Rosini (2017) yang melakukan kajian terhadap perilaku hidup sehat lainnya, yaitu pemberian literasi 
informasi kesehatan tentang "menggosok gigi" dengan menggunakan media edukomik. Dari hasil penelitian tersebut, disimpulkan bahwa terdapat pengaruh pemberian literasi informasi kesehatan dengan menggunakan edukomik cara menggosok gigi terhadap peningkatan pengetahuan cara menggosok gigi pada anak-anak usia dini. Kajian lainnya yang tak jauh hasilnya dengan penelitian ini disampaikan oleh Hadi, Sugiarto, K.Y, \& Rahmah (2012), yaitu hasil penelitian yang menunjukan adanya pengaruh penyuluhan kesehatan demam berdarah dengue (DBD) dengan media komik terhadap perilaku pencegahan DBD.

\section{KESIMPULAN}

Berdasarkan hasil analisis yang telah diuraikan sebelumnya maka dapat disimpulkan bahwa terdapat pengaruh pemberian literasi informasi kesehatan perilaku hidup sehat yaitu cara mencuci tangan melalui media edukomik terhadap peningkatan pengetahuan perilaku hidup bersih sehat tentang mencuci tangan. Media edukomik untuk edukasi menjadi sarana yang tepat dalam menyampaikan pesan yang bermuatan edukasi, terutama kepada anak-anak usia dini dan usia sekolah. Untuk kedepan disarankan untuk meneliti indikator lainnya dalam PHBS bisa dengan media edukomik atau dengan menggunakan media lainnya. Atau sebaliknya media edukomik dapat digunakan untuk promosi bidang kesehatan lainnya sehingga dapat ditentukan media yang paling cocok.

\section{DAFTAR PUSTAKA}

Bredekamp, S. (1992). Reaching Potentials: appropriable curriculum and assessment for young children Title (Volume 1). Washington DC: National Asso. for the Education of Young Children.

Dhien, K. (2006). Perancangan Komik Hyang Dalam Menumbuhkan Apresiasi Generasi Muda Kepada Kesenian Wayang. Skripsi. Surakarta: Fakultas Sastra dan Seni Rupa Universitas Sebelas Maret. Retrieved from https://eprints.uns.ac.id/2484/1/56921006200907201.pdf

Hadi, C., Sugiarto, S., K.Y, M., \& Rahmah, Z. (2012). Pengaruh penyuluhan kesehatan dengan media komik tanggap DBD terhadap peningkatan pengetahuan dan sikap tentang pencegahan DBD di SDN Banjarejo Ngadiluwih Kabupaten Kediri. In Seminar Nasional Competitive Advantage. Jombang: Unipdu Jombang. Retrieved from http://journal.unipdu.ac.id/index.php/seminas /article/view/177 
Kementerian Kesehatan. (2010). Rencana strategis kementerian kesehatan tahun 2010-2014. Jakarta, Indonesia.

Kementerian Kesehatan. (2011). Pedoman Pembinaan Perilaku Hidup Bersih dan Sehat (PHBS). Jakarta, Indonesia.

Koh, H. K., Brach, C., Harris, L. M., \& Parchman, M. L. (2013). A Proposed "Health Literate Care Model” Would Constitute A Systems Approach To Improving Patients' Engagement In Care. Health Affairs, 32(2). Retrieved from https://www.healthaffairs.org/doi/full/10.1377/hlthaff.2012.1205

Maharsi, I. (2011). KOMIK: Dunia Kreatif Tanpa Batas. Yogyakarta: Kata Buku.

Migotuwio, N. (2013). Komik Indonesia. Retrieved July 23, 2019, from https://www.academia.edu/6992644/Komik_Indonesia.

Proverawati, A., \& Rahmawati, E. (2012). Perilaku Hidup Bersih dan Sehat. Yogyakarta: Nuha Medika.

Rosini. (2017). Pengaruh Literasi Informasi Kesehatan Melalui Edukomik Terhadap Peningkatan Pengetahuan Menggosok Gigi Pada Anak Usia Dini. Jurnal Bibliotech, 2 (1), 40-51.

Soedarso, N. (2015). Komik: Karya Sastra Bergambar. Humaniora, 6 (4), 496-506. Retrieved from https://journal.binus.ac.id/index.php/Humaniora/article/view/ 3378/2757

Soedjana, N., \& Rivai, A. (2011). Media Pengajaran. Bandung: Sinar Baru Algesindo. Sugiyono. (2014). Metode Penelitian Kombinasi (Mixed Methods). Bandung: Alfabeta. 